\title{
تأثير التدريبات البصرية على وظائف الرؤية الرياضية لدى ناشئ كرة القدم بلدولة الكويت
}

* أ.د/عبدالحكيمرزق عبلالحكيه

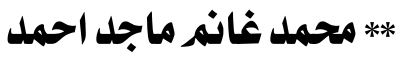

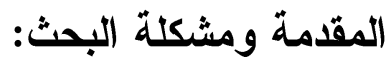

تلعب الأجهزة الحسية المختلفة دوراً هاماً أثثاء أداء المهار ات التي تؤدى بشكل منفرد وتتطلب استجابة واحدة أو لعدد من المهارات التي تتميز بالتز ابط وتكون إحداها

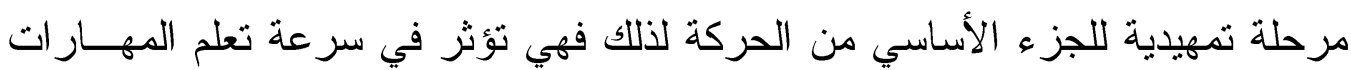

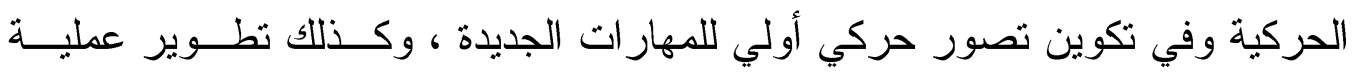
التو افق بالنسبة للحركات المركبة ، مما يؤدى إلى القدرة على التحكم في الحركات بدقة التهات و الاحتفاظ بالأوضاع الحركية السليمة وبالتالي الوصول بلوكل إلى تكامل الأداء الحركي.

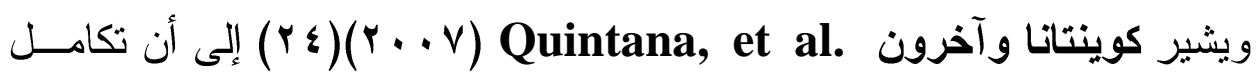

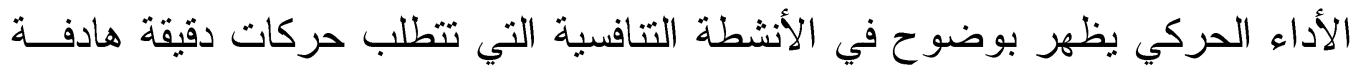

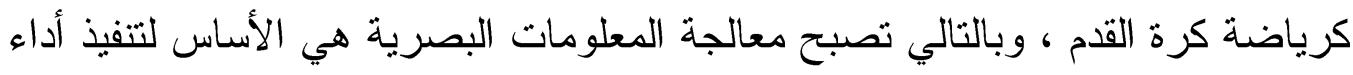

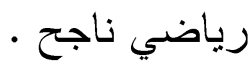

و الإبصار هو الحاسة التي يمكن من خلالها عن طريق العضو المخــتص وهــــ

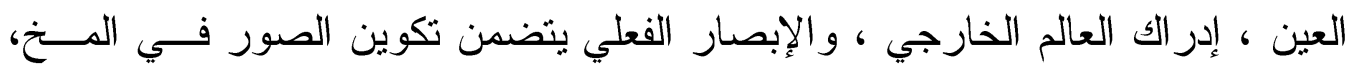
وتختلف درجات وضوح الصور باختلاف عيون الكائنات المختلفة.

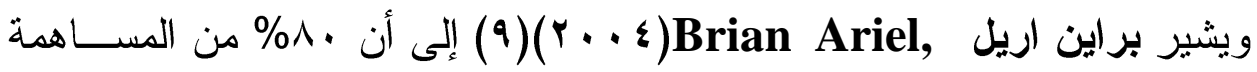
الإدر اكية في الأنشطة الرياضية تعتبر بصرية ، وان 90\% من الحيل الحركات الرياضية ينت

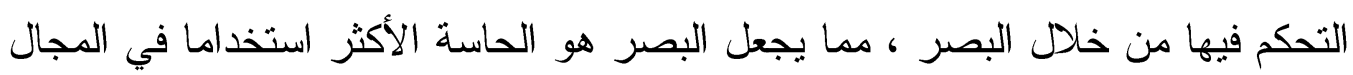

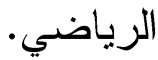




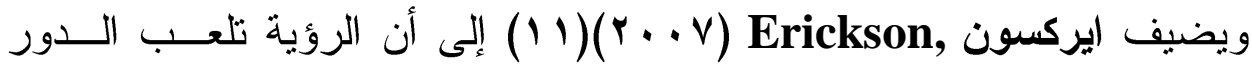
الأكبر في توجيه و استجابة العضلات ، حيث تزود اللاعب بالمعلومات اللزمة لتحديد

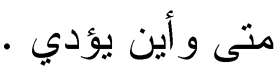

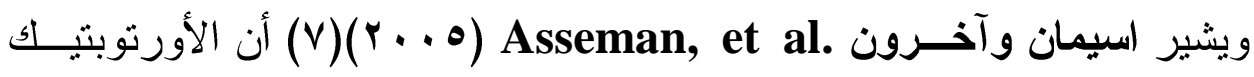
Orthoptic

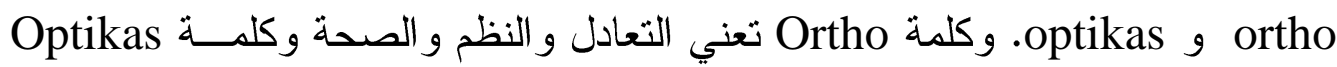
تعني البصر والنظر الكافي. لذلك كلمة الأورتوبتيك تعني إيجاد التنسيق في البصر .

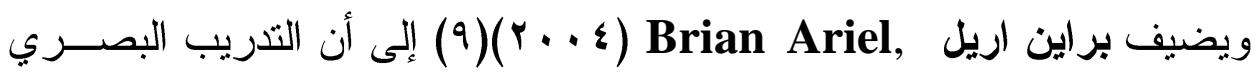
احد فروع (الاوبتومترى Optometric) قياسات النظر وهو فــرع بهــتم بــالنظر و الإدر اك وتقييم وتحسين مستوى الأداء البصري بالإضافة إلى تحديد الأدوات البصرية

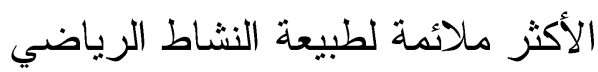

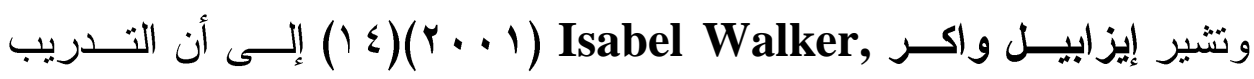
البصري يعتبر إحدى وأخر الثقنيات المعروضة في المجال الرياضي بهـدف تحسـين الأداء الرياضي و اكتساب ميزة تتافسية ، وهو عبارة عن سلسلة متكررة لتدريبات العين بهدف تحسين القدرات البصرية الأساسية ، وهى هامة للرياضيين في جميع الرياضات التنافسية.

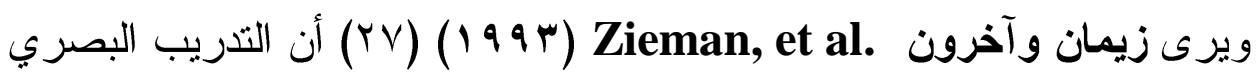

في المجال الرياضي يعتبر منطقة صغيرة نسبيا في منظومة الأداء الرياضـــي ولكنهـــا كبيرة الأهمية ، و أصبح الاهتمام بها كبير ا وبشكل متز ايد ونشط في الفتر ات الأخيرة.

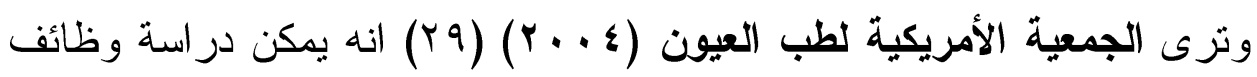

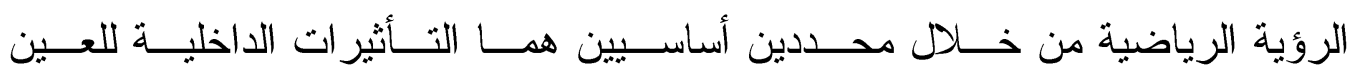
و التأثير ات الخارجية للعين (Hardware) يقصد بها كفاءة العين الداخلية كقوة الإبصار وكفائتة وكل ما يتعلق بمكونـات العــين 
الداخلية كضغط العين وغيرها و هذه يتم استخدامها في المجال الطبي بكثـرة كعـلاج

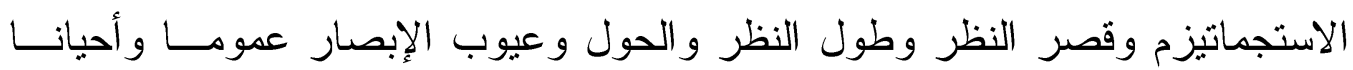
تحتاج هذه البر امج إلى مدة طويلة قد تستغرق سنوات للعلاج ونتائجها ماز الت محـل نقاش وجدل دائمين ، أما التأثير ات الخارجية للعين فيقصد بها تحســين كفــاءة العــين الخارجية من خلال تحسين كل ما يتعلق بالأداء النوعي في الحياة عامة وفي المجــال

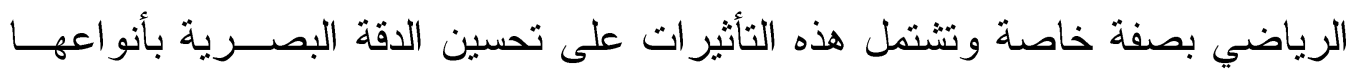

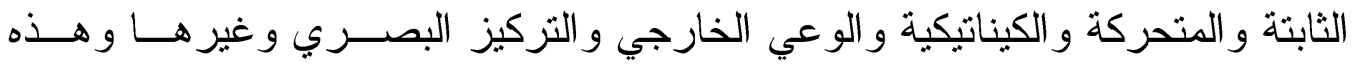
تستخدم في المجال الرياضي بصورة كبيرة ونتائجها دائما تكون أكثر من المنوقع. ويعد التصويب في القدم من أهم المبادئ الأساسية للعبة، وتعتبر إصابة الهـدف المحصلة النهائية للأداء، و العامل الحاسم في تحديد نتائج المبار اة.

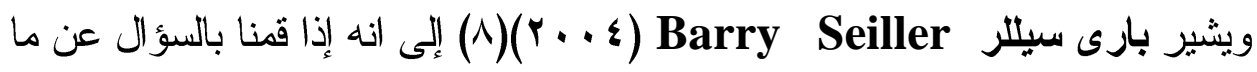
هو الثيء الذي يميز أفضل للاعبين في الرياضات الجماعية ، البعض قد يرى المتغيــرات الجسمية ومنهم من يرى أن قوة مفصل رسخ اليد و البعض يرى إنها القدرة على المحاورة ،

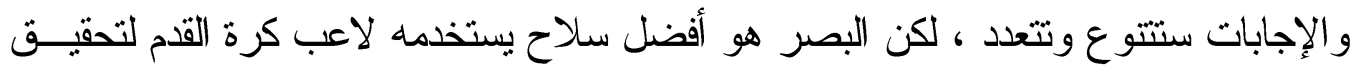

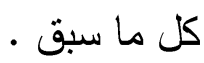

وعن أهمية المهار ات البصرية في مجال رياضة كرة القدم بشير إلى أن المهــار ات البصرية تعتبر الأكثر أهمية لدى لاعب كرة القدم ، وان قضاء الساعات الطويلة من التخريب وممارسة كرة القم تعتبر عديمة الجدوى إذا افتقر اللاعب للمهار ات البصــرية ، فالمهــارات البصرية هي مفتاح التو افق والتوقيت و الأداء الإجمالي في كرة القدم •

وعن ارتباط مهارة التصويب في كرة القدم بالمستقبلات الحسية يشير طارق شــري

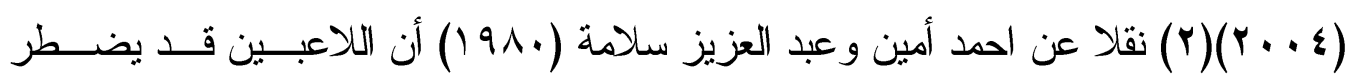
للتصويب وهو في وضع غير متزن مما يؤثز على خط سير الكرة لعدم أحساسة الصــحيح

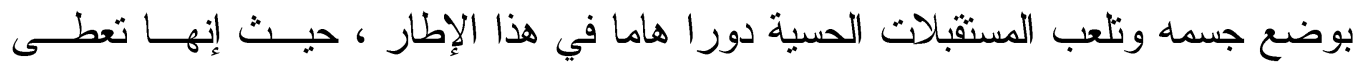
إحساس بعدم ثبات المفاصل والتي لها علاقة بين الجهاز العصبي و الجهاز العضلي . 


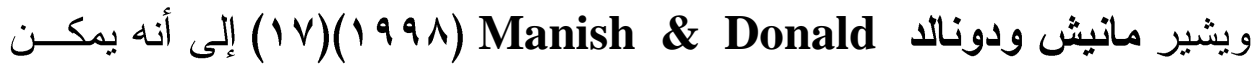

التعرف على الصعوبات البصرية من خلال ملاحظة الأخطاء التالية :

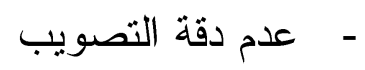

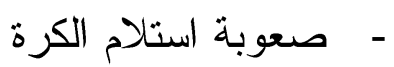
- معوبة تمرير الكرة

- صعوبة تحديد اللاعب لمركزة في ضوء مر اكز أعضاء فريقــه ، الحـدود الجانبية للملعب و الشبكة . ملبه

- معوبة إجر اء الهجمة السريعة المرتدة Fast Break

ومن خلال خبرة الباحث كلاعب ومدرب ومعرفته بأهمية القـدر ات البصــرية لرياضة كرة القدم فرياضة كرة القدم من الرياضات التي تعتمد بدرجة كبيــرة علــى الكثير من القدر ات البصرية وهذا يرجع إلى طبيعة اللعبة وسرعة الأداء ، مما يتطلب

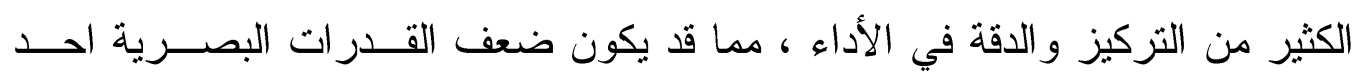
Pierre الأسباب الرئيسية لضعف مستوى الأداء ، وفي هذا الصدد يرى بيير المــور Elmurr,

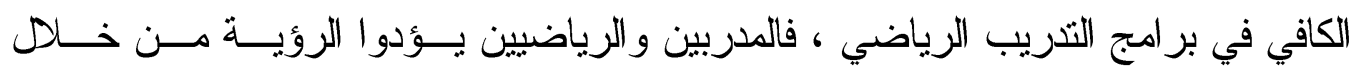

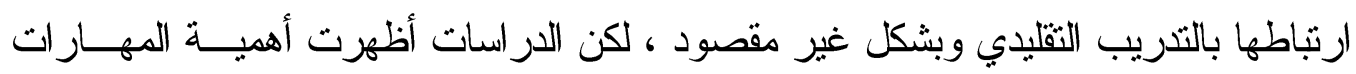

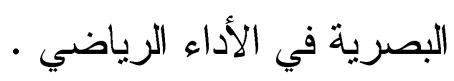

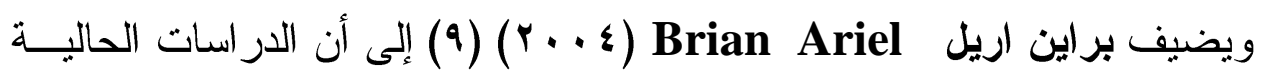
ثشير إلى أن • ب\% من الرياضيين لديهم قصور في الدقة البصرية أو الرؤية الصحيحة و البيانات الخاصة بلاعبي و لاعبات اولمبياد ب99 ام تشير إلى الأتي :

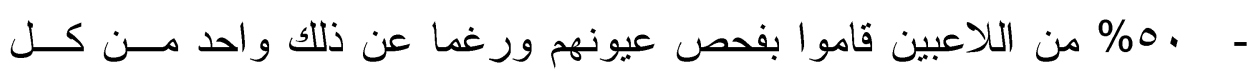
أربعة لاعبين لدية صعوبات بصرية 


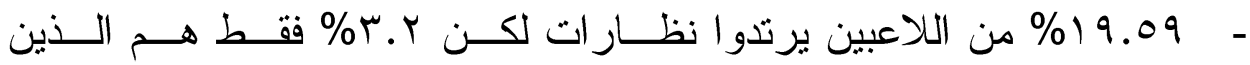
يستخدمو ها في النشاط الرياضي مقارنة ب س.ء 9\% يرتدوا عدسات لاصقة

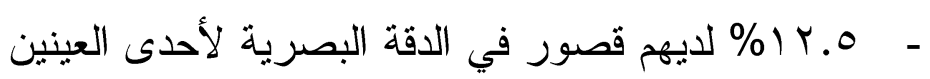

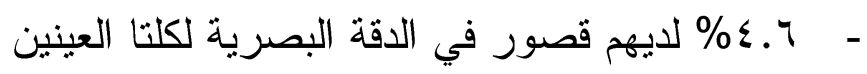

ومن خلال الإطلاع على الثبكة العالمية للمعلومات (الانترنت) و على ما أتـيح للباحث من دراسات ومراجع ، وفي حدود علمه عدم تتــاول أي در اســـة للتـدريبات

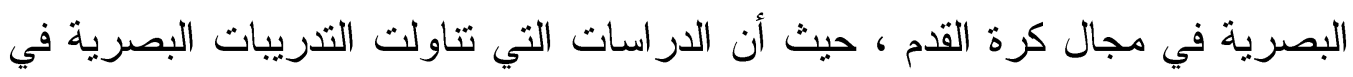

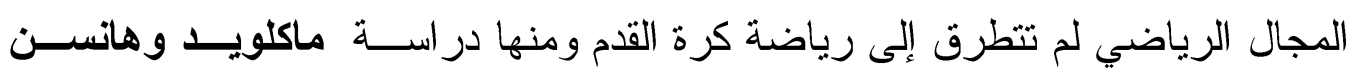
(

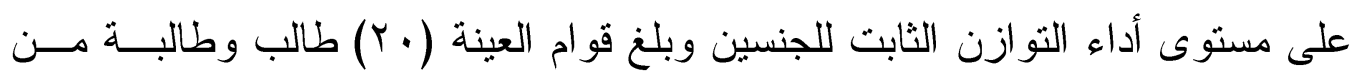
كليات التربية الرياضية تتر اوح أعمار هم من (9 1-سب عام) نم تقسيمهج عشو ائيا إلـى

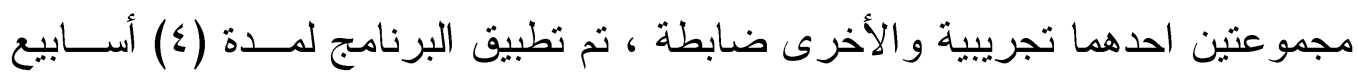
وكان من أهم النتائج تفوق المجموعة التجريبية في مستوى أداء التوازن الثابت مقارنة بالمجموعة الضـابطة وتفوق قياسات البنات مقارنة بالبنين في مســتوى أداء التـــوازن

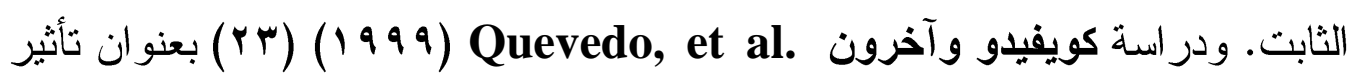
التدريبات البصرية على مستوى الأداء في الرماية وبلغ قو ام العينة (V) طالب جامعي تم تقسيمهم عشو ائيا إلى مجمو عتين (تجريبية وضابطة) وبلغت مدة البرنامج (9) أسابيع وكان من أهم النتائج تفوق المجموعة التجريبية في مهارة الدقة البصرية وعدم وجــود فروق بين المجمو عتين في مستوى أداء التصويب ـ ودر اسة كالار ونواكس Calder أم \& Noakes

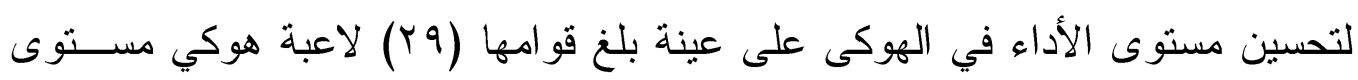
عالي تم تقسيمهم إلى (r) مجموعات (اثثين تجريبية وو احدة ضــابطة) ، المجموعــة التجريبية الأولى خضعت لبرنامج تدريب بصري نوعى وتدريبات وعــى بصــري ، و المجموعة التجريبية الثانية خضعت لتدريبات رؤية تقليديــة ، و المجموعـــة الثالثــة 
مجموعة ضابطة ، وبلغت مدة تطبيق البرنامج (^) أسابيع وكان من أهم النتائج وجود فروق دالة إحصائيا في مستوى الأداء لصالح المجموعة التجريبية الأولى حيث تحسن ونى

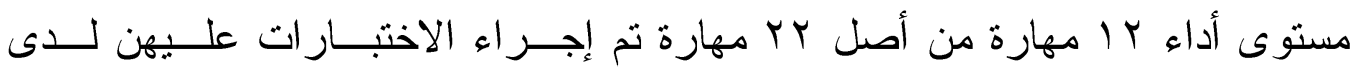
المجموعة التجريبية مقارنة بتحسن مهارتين فقط للمجموعة التجريبية الثانيــة و عــدم

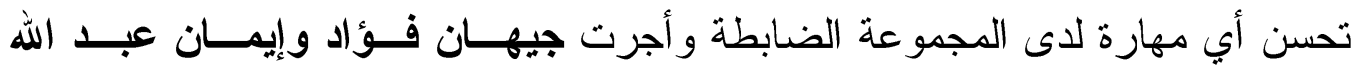

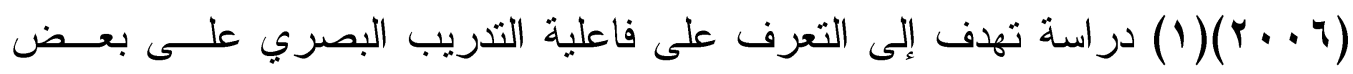
المتغير ات المهارية والقدرات البصرية في الكرة الطائرة، واستخدمت الباحثثان المنهج

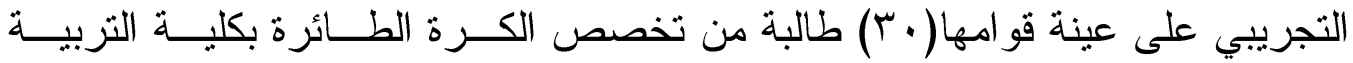
الرياضية للبنات جامعة الزقازيق وتم تقسيم العينة إلى مجمو عتين قو ام كل منها (10) طالبة نم تطبيق برنامج التدريبات البصرية على المجموعة التجريبية، ونوصلت النتائج إلى أن البرنامج البصري المقترح له فاعلية في تحسين القدر ات البصرية وكذلك تحسين مهار ات الكرة الطائرة - وكانت أقل نسبة تحسن في كفاءة الإبصار ، سرعة رد الفعل

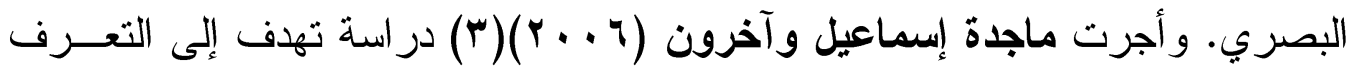

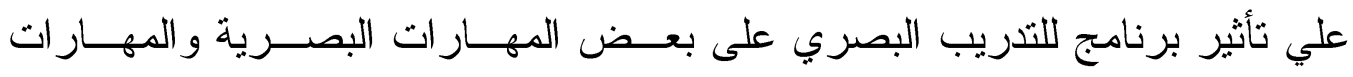

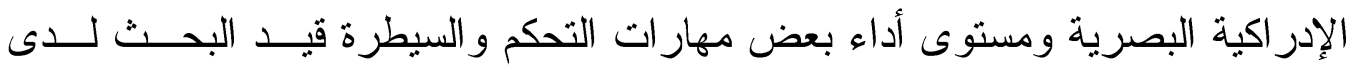
ناشئات الجمباز الإيقاعي ، استخدمت الباحثات المنهج التجريبي لمجموعتين إحــــاهما

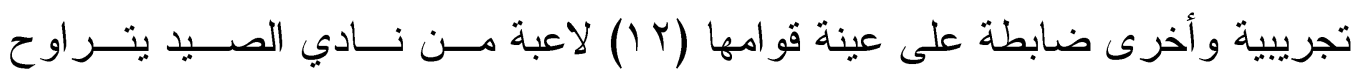

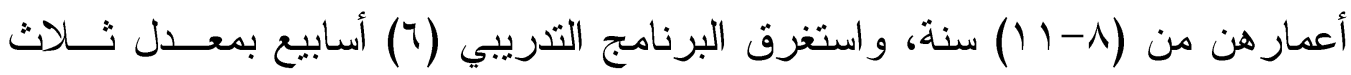

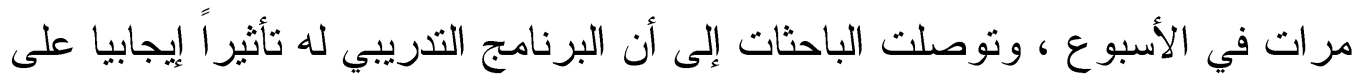

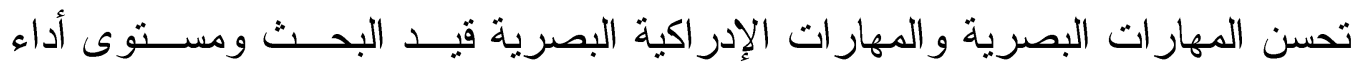
مهار ات التحكم و السيطرة لدى الناشئات ، كما أن هناك علاقة ارتباطيه بين المتغيرات

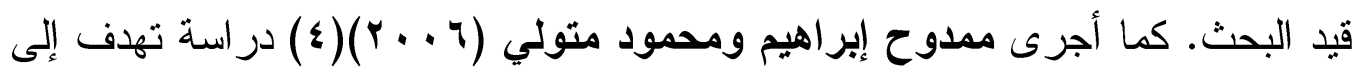
التعرف على أساليب تطوير التمرير المتنوع في أجزاء الملعب وتأثير ها على الكفــاءة الوظيفية لبعض المدركات الحسية (البصرية سو الحركية) لاى ناشئ كرة القدم ، استخدم الباحثان المنهج التجريبي على عينة قو امها (ب (1) ناشئ لكرة القدم من نادي الثــرقية 
بالزقازيق وتم تطبيق البرنامج التدريبي لتحسين المدركات الحســية الحركيــة (إدر الك مجال الرؤية - إدر الك العمق). وتوصلت النتائج إلى حدوث تحسن فــي إدر الك مجـــال

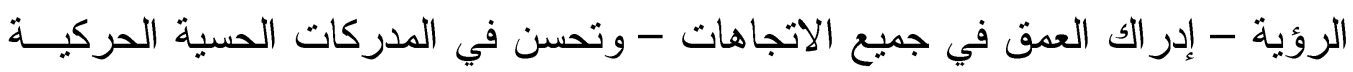

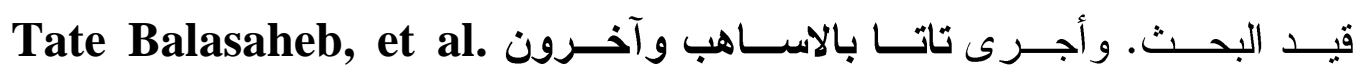

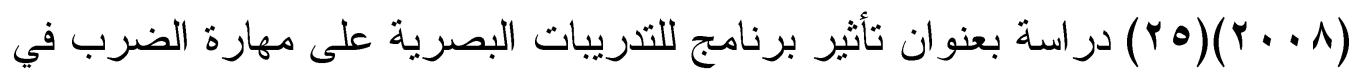

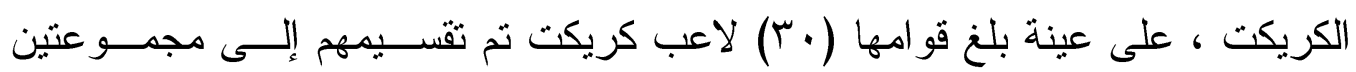
بالتساوي احدهما تجريبية و الأخرى ضـابطة ، وبلغت مدة برنامج التدريبات البصــرية

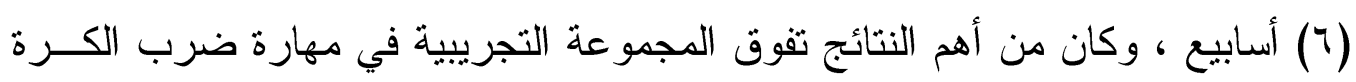

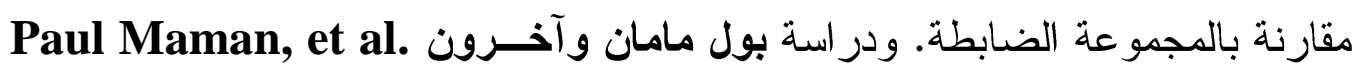

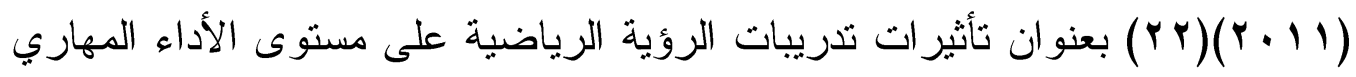

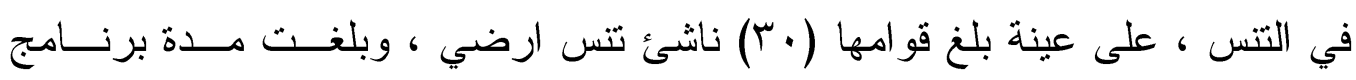
تدريبات الرؤية الرياضية (^) أسابيع ، وكان من أهم النتائج أن البرنامج المقترح أسهر في تحسن بعض المهارات البصرية ومستوى الأداء في التنس . أو در اسـات أجريت بهدف التعرف على القدرات البصرية في المجال الرياضـي

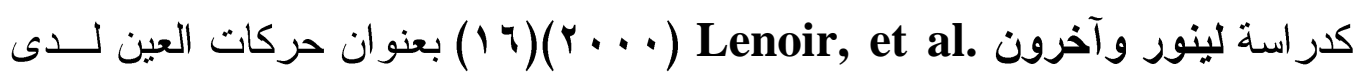
لاعبي التنس الطاولة في مستويات مختلفة ، وبلغ قو ام العينة (ro) لاعب تتس طاولة ،

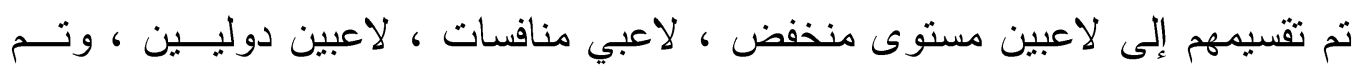

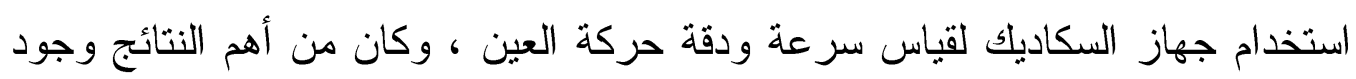
فروق ذات دلالة إحصائية بين عينات البحث لصالح اللاعبين الدوليين في سرعة ودقة

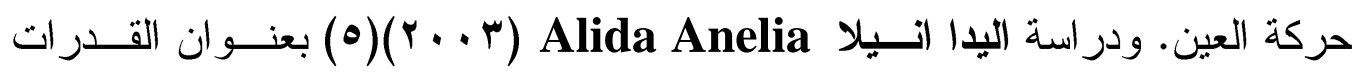
البصرية للاعبي الرجبي المحترفين و الهواة ،وذلك بهدف مقارنة القـدر ات البصــرية للاعبي الخط الأمامي و الخط الخلفي في الرجبي للمحترفين و الهواة ، وبلغ قو ام العينــة

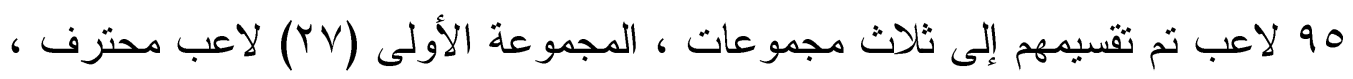

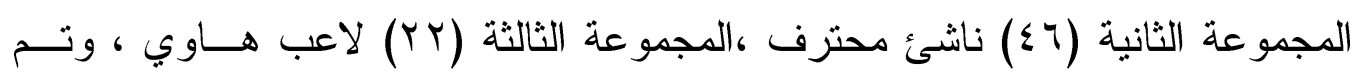


قياس الوعي الخارجي المركزي ، تو افق العين و اليد ، تو افق العين والجسم ، ســرعة

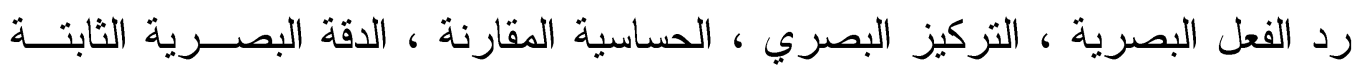

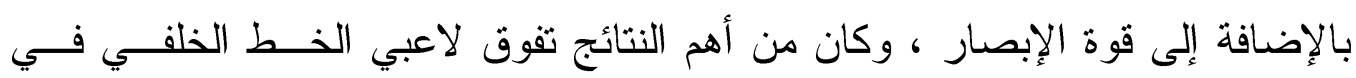
المجموعة الأولى في اختبارات الوعي الخارجي المركزي وسرعة رد الفعل البصرية وتو افق العين و اليد والدقة البصرية الثابتة وتفوق المجموعة ككل في اختبار ات الوعي Mazyn, et الخارجي المركزي وسرعة رد الفعل البصرية. ودر اسة مازين وآخرون

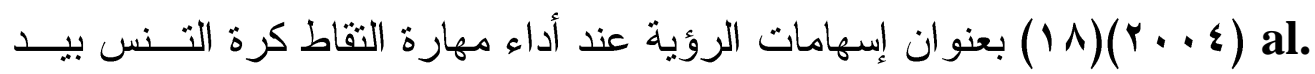

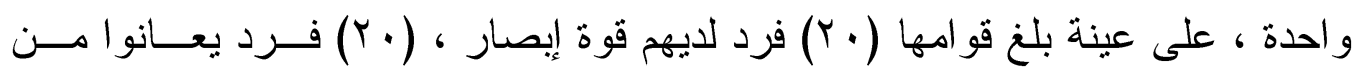

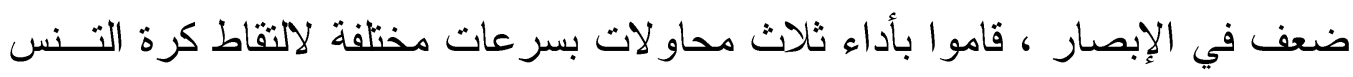
بيد واحدة في حالة غلق إحدى العينين وفتح كلتا العينين ، وتم استخدام كاميرات فيديو لإجراء التحليلات اللازمة لحركات العين ، وكان من أهم النتائج وجود ارتباط عكسي بين سرعة الكرة والتقاطها فكلما زادت سرعة الكرة ظهر انخفاض مستوى أداء التقاط كرة التنس ، وعدم وجود فروق في حالة استخدام كلتا العينين أو عين واحدة للمجموعة

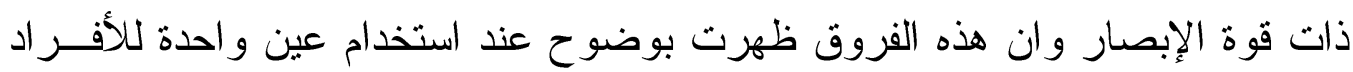

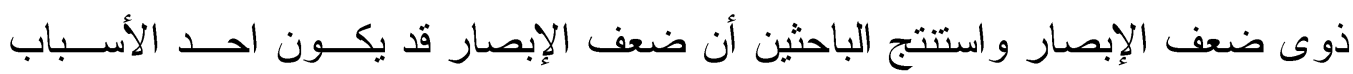
الرئيسية في عدم تحقيق الانجاز الرياضي. ودر اسة ميلسلاجل Millslagle, ( . . . ب)

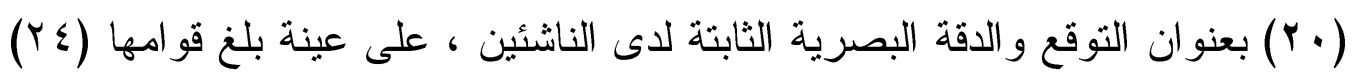

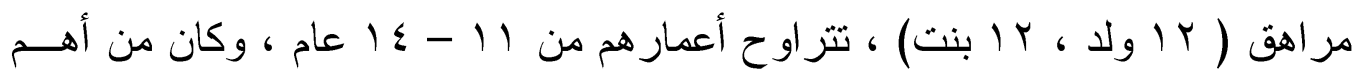
النتائج تفوق الأولاد على البنات في متغير الدقة البصرية الثابتة وعدم وجود فروق بين

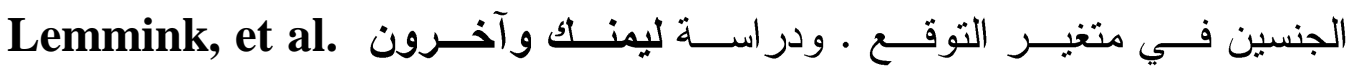

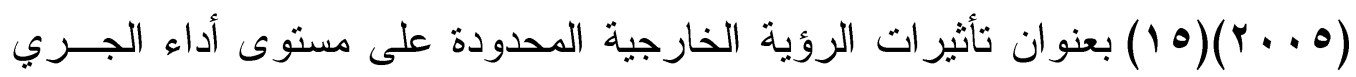

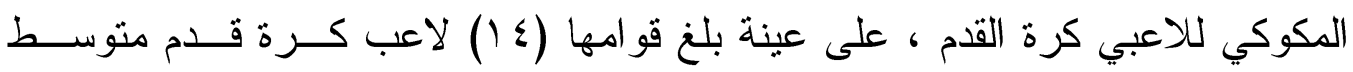

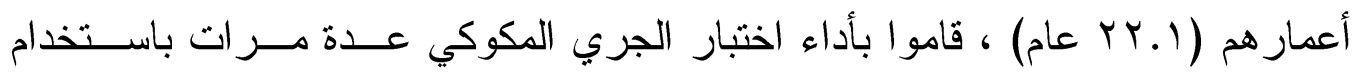
الرؤية الخارجية الكاملة والمحدودة لميدان الاختبار ، وكان من أهم النتائج تتاقص زمن الأداء عندما تم استخدام الرؤية الخارجية المحدودة ، حيث إنها ساهمت فـي تحســين 
Asseman, et al. القدرة على تغيير الاتجاهات بسر عة. ودر اسة اسيمان وآخرون

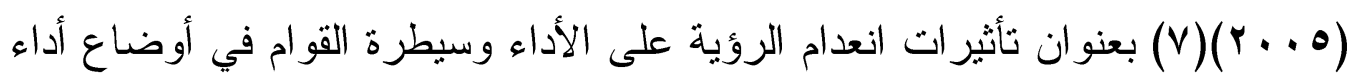
مختلفة للاعبي الجمباز الموهوبين ، وبلغ قو ام العينة (Y) ( ) لاعب جمباز ، قاموا بأداء ثلاث أوضاع مختلفة (الوقوف على القدمين ، الوقوف على قدم واحدة - الوقوف على الى اليدين ) مرة بغلق العينين والأخرى بفتحها وكان من أهم النتائج عدم وجود اختلاف في

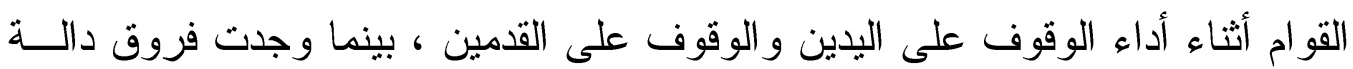
عند أداء الوقوف على قدم واحدة واستتتج الباحثون أن البصر يؤثر بشكل غير مباشــر على الأداء و التحكم في القو ام و انطلاقا مما سبق سيقوم الباحث بالتطرق إلـى دراســـة تأثير ات التدريب البصري في كرة القدم لدى ناشئي كرة القدم بدولة الكويت هدف البحث :

يهدف البحث إلى التعرف على تأثير التذريبات البصرية على وظــائف الرؤيسـة الرياضية لدى ناشئ كرة القدم بدولة الكويت

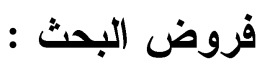

'. توجد فروق دالة إحصائبا بين القبــاس القبلــي و البعـــي للمجموعــة التجريبية في بعض الوظائف البصرية لصالح القياس البعدي.

Y. توجد فروق دالة إحصائيا بين القياسين البعديين للمجموعتين التجريبيــة و الضابطة في بعض الوظائف البصرية لصالح للمجموعة التجريبية.

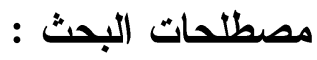

\section{توافق العين - اليا والجسم Eye - Hand - Body coordination}

يقصد بها كيف تستجيب يديك وجسمك للمعلومات التي تم جمعهــا مــن خــلال العين، وتعتبر مكون هام في اغلب الألعاب الرياضية لأنها تؤثر على التوقبت والتحكم

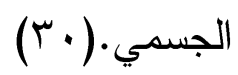


Visual Acuity الدقة البصرية

هي الهدف الذي يمكن تحقيقه من خلال التحكم بالعمل الإز ادي وفقــــ للتو افـقـ العالي بين الجهازين العصبي و العضلي ، وبذلك فان الدقة هي مقدار رقمي أو وصفي

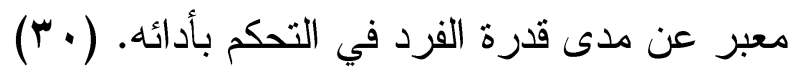

Depth Perception إرالك العمق

الحكم و اتخاذ القر ار بسرعة على سرعة ومسافة الهدف وتتطلب تقــدير مســافة

$$
\text { وسرعة الهدف.(• (r) }
$$

\section{Visual Memory الاكرة البصرية}

تذكر الصور و الأشكال ومو اقف اللعب المختلفة والخبر ات السابقة واستخدامها في

التغذية الر اجعة أثناء الأداء ـ (ra)

Eye Tracking التبع البصري

تتبع وملاحظة سمات الهدف (الكرة) مهما زادت سرعتها أو اختلفت. ( • )

إجراعات البحث : | (إ)

منهج البحث :

استخدم الباحث المنهج التجريبي باستخدام التصميم التجريبــي ذو المجمــوعتين إحداهما تجريبية و الأخرى ضابطة بالقياسات القبلية و البعدية وذلك لملائمتـــة لتطبيــق لقئق

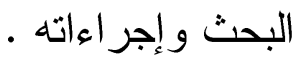

عينة البحث:

تم إختيار عينة البحث بالطريقة العمدية من بين ناشئ كرة القدم بنادي العربـي

الكويتي ، وقد بلغ عدد إجمالي عينة البحث (ro) ناشئ كرة قدم ، وقد استبعد الباحسـث

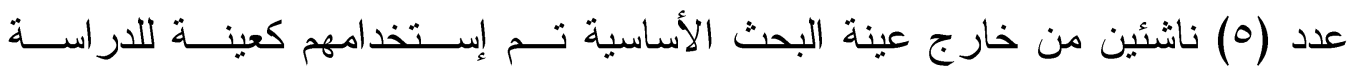




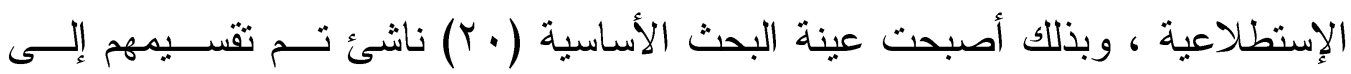

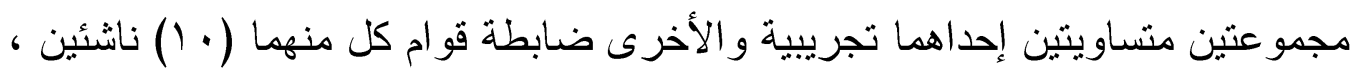
وقد قام الباحث بإجر اء التجانس في الطول و الوزن و العمر الزمني و العدــر التــدريبي و الجدول رقم (1) يوضح ذلك.

جدول (1)

تجانس عينة البحث في الطول والوزن والعمر الزمني والعمر التدريبي

$r \bullet=\dot{0}$

\begin{tabular}{|c|c|c|c|c|c|c|}
\hline معامل الالتواء & الوسيط & الآحر افياري & الوسط & وحدة القياس & المتغيرات & p \\
\hline $1 . .1$ & |Ar.l| & $7 . .7 \pm$ & 110.17 & سم & الطول & 1 \\
\hline $.9 r$ & $79 . \vee \wedge$ & $0.01 \pm$ & $V I \leqslant V$ & كجم & الوزن & $r$ \\
\hline Tr & $10 . \mu$. & $1 . r \leqslant \pm$ & 10.19 & سنة & العمر الزمنى & $r$ \\
\hline $.7 \varepsilon$ & S.YY & $r .17 \pm$ & $\{.71$ & عدد & العمر التدريبي & $\varepsilon$ \\
\hline
\end{tabular}

يتضح من الجدول رقم (1) أن قيم معامل الالتو اء انحصرت ما بين 土ب مما يدل على تجانس عينة البحث أدوات ووسائل جمع البيانات :

قام الباحث بإجر اء مسح للمراجع و الدر اسات السابقة المرتبطة و المشابهة لتحديد المتغير ات البصرية و المهارية و الاختبار ات الخاصة بهر

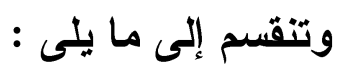

أولاً: الأجهزة والأدوات المستخدمة في البحث :

• جهاز الرستامير لقباس إرتفاع القامة

• ميزان طبي معاير لقياس الوزن

شريط قياس 
كرات تتس ملونة

كرات سلة عليها استيكرز (علامات ملونة )

كر ات ملونة بداخلها جرس

أطو اق بلاستيك ملونة

نظار ات بيضاء مظللة

ألو اح خشبية ملونة

ثانياً: اختبارات الوظائف البصرية المستخدمة في البحث: مرفق (1)

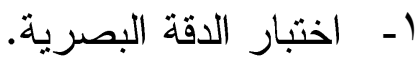

r- - - اختبار التتبع البصري. r- إختبار رد الفعل البصري البسيط. ع- اختبار إدرالك عمق الرؤية. 0ـ - اختبار إدرالك مجال الرؤية. ד- اختبار تو افق العين و القدم.

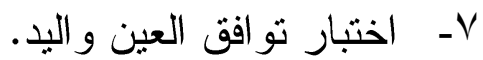
1- م- الذاكرة البصرية الار اسة الإستطلاعية : الإهن

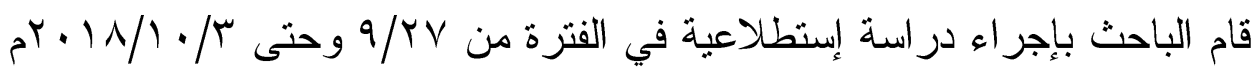
على ناشئ العينة الإستطلاعية و عددهم(0) ناشئين، و استهدفت هذه الدر اسة: - التأكد من صلاحية الأدوات و الأجهزة المستخدمة، - معرفة زمن وفترة الاختبار ات و إعادة تقنين بعض الاختبار ات - وضع المحتوى التذريبي للبرنامج وتقنين وحداته وتحديد الأزمنة و التكـــرار

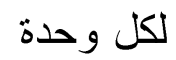
- 


$$
\text { المعاملات العلمية (الصدق - الثبات): }
$$

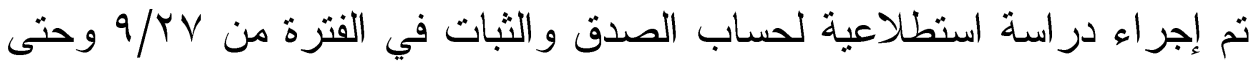

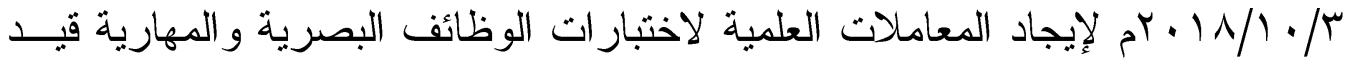

\section{أولاً: حساب معامل الصدق:}

لحساب معامل صدق التمايز قام الباحث بتطبيق الإختبار ات البصرية و المهارية

على أفر اد العينة الإستطلاعية (عينة غير مميزة) و عددهم (0) أعضاء من نادى بنادي العربي الكويتي وغير الممارسين لأنشطة رياضية كما نم تطبيق نفس الإختبار ات على

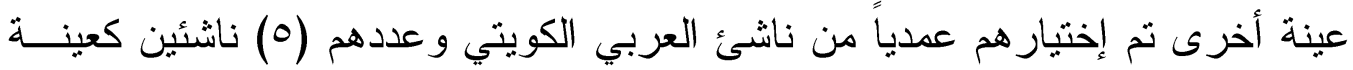
مميزة، وذلك بهدف معرفة زمن وفترة تطبيق الاختبار ات وإجر اء المعاملات العلميــة (ثبات - صدق) لاختبار ات الوظائف البصرية و المهارية المســتخدمة فــي إجــر اءات البحث وقد تم حساب ثبات الاختبارات عن طريق تطبيق الاختبار ثم إعادة تطبيقه على أفر اد العينة الاستطلاعية وبفاصل زمني قدرة ثلاثة أيام ، كما تــم حســاب صــدق الاختبار ات عن طريق حساب صدق التمايز بين العينة غير المميزة والعينـــة المميـزة (العربي الكويتي) ويوضح الجدول رقم (Y) المعاملات العلمية. 


\section{جدول (r) (بد)}

المعاملات العلمية (الثبات -صدق التمايز) للاختبارات البصرية والمهارية

1. $=0$

\begin{tabular}{|c|c|c|c|c|c|c|c|c|c|c|c|c|}
\hline \multicolumn{5}{|c|}{ صدق الاختبارات } & \multicolumn{5}{|c|}{ ثبات الاختبارات } & \multirow{3}{*}{ ولقياس } & \multirow{3}{*}{\multicolumn{2}{|c|}{ البيان }} \\
\hline قيمة & \multicolumn{2}{|c|}{ العينة المميزة } & \multicolumn{2}{|c|}{ العينة غير المميزة } & \multirow{2}{*}{ الاستثر رار } & \multicolumn{2}{|c|}{ التطبيق الثاني } & \multicolumn{2}{|c|}{ التطبيت الأول } & & & \\
\hline " & $r \varepsilon$ & $r^{p}$ & $\varepsilon$ & م & & $r_{\varepsilon}$ & $r_{p}$ & $1 \varepsilon$ & $1_{p}$ & & & \\
\hline T.rV & $1 . \varepsilon$ & 9.19 & $1.7 \mathrm{~V}$ & $7.1 Y$ & $.9+\varepsilon$ & I.Ar & $9 . \leqslant \leq$ & $1 . \varepsilon$. & 9.19 & عدد & بين العين واليا & التوافق \\
\hline$V . V V$ &..$\leqslant 1$ & 9.71 & Y.Y. & $1 \varepsilon . .1$ & .94. &. .29 & 9.1. &.$\leqslant 1$ & 9.71 & عدد & بين العين والقدم & التوافق \\
\hline Y.r. & $1 . v V$ & W & $1.0 \mathrm{~V}$ & $\Lambda .01$ &.$\wedge \wedge r$ & $1 . V \varepsilon$ & 11.9. & $1 . V V$ & 11.r & عدد & صرية & الدقة (لب \\
\hline 9.v० &.$r$. & Y.91 &.$Y 4$ & T.rV & .9 .1 & דו & Y.A० &.$r$. & Y.91 & لدرجة & البصرية & الأكرة | \\
\hline $0.0 \mathrm{r}$ & 1.87 & O.Yr & $1.1 \varepsilon$ & Y.A乏 & $\cdot 9 \cdot \varepsilon$ & $1.0 \mathrm{~V}$ & O.rA & 1.87 & D.rY & درجة & بصري & التبع الب \\
\hline V.rی & $\ldots \wedge$ &.$\wedge \varepsilon$ & $\cdots 9$ & .94 & .941 & $\ldots 0$ &.$\wedge \bullet$ & $\ldots \wedge$ &.$\wedge \varepsilon$ & ثانية & رد الفعل & سرعة ر \\
\hline 0.17 &. .79 & $0 . \wedge 1$ & r & T.AY & .907 & .07 & $0.7 \varepsilon$ &. .79 & 0.11 & سم & من مسافة • 1 سم & إدر (ك \\
\hline $7 . V V$ &. $.7 V$ & V.TH & $.0 \leqslant$ & A.r. & $.9 r v$ & .01 & V.TY & $.9 V$ & V.Tr & سم & من مسافة • ب سم & عمث \\
\hline q.V० &. $.0 \wedge$ & 9.01 & $\because 0$ & $1 . .9 \mathrm{~V}$ & .911 &.$v V$ & 9.01 &. .01 & 9.01 & سم & من مسافة • بسم & الروئية \\
\hline A.YI & Y.OV & $70 . \leqslant T$ & r... & 71.10 & $\because 9 \leq 7$ & Y.ro & $7 \leq . \wedge 9$ & Y.OV & $70 . \leqslant \%$ & سم & سي لأعلى & \\
\hline$\varepsilon . \vee \wedge$ & r.ro & TO.YY & T.1 & $7 . .1$. & .940 & T.rV & 70.7. & T.Yo & TO.YY & 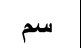 & |-رأسي لأسفل & \\
\hline $7.7 \varepsilon$ & r.VT & VI.AT & r. $\varepsilon q$ & 79.0. & .947 & 1.91 & V1.9. & r.VT & VI.AT & سم & |-فقي يمين & $\pi$ \\
\hline$\wedge . \vee \wedge$ & Y.MY & VY.TV & 1.7 & TV.r. &.$\wedge \vee \bar{~}$ & 1.99 & VY.A. & Y.rY & VY.TV & سم & |- أفقي شمال & \\
\hline
\end{tabular}

يتضح من الجدول رقم (r) وجود علاقة ارتباطيه دالة إحصائياً عنــد مسـتوى ه .. بين التطبيقين الأول والثاني لاختبار ات الوظائف البصرية ، مما يشير إلى ثبات هذه الاختبار ات، كما يتضح وجود فروق دالة إحصــائياً عنــــ مســتوى ه . . . بــين المجمو عتين المميزة وغير المميزة في الوظائف البصرية قيد البحث.

\section{برنامج التدريبات البصرية المقترح :}

يهدف البرنامج المقترح باستخدام التدريبات البصرية إلى تتمية وتطوير الوظائف البصرية للعين لدى ناشئ كرة القدم بنادي العربي الكويتي. 
أسس بناء البرنامج التدريبي المقترح :

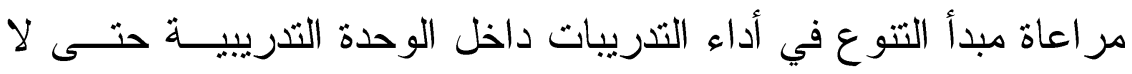

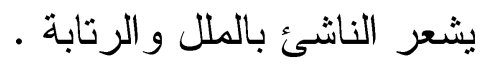

مناسبة المحتويات المختارة للمرحلة السنية

إتباع مبدأي التدرج من السهل إلى الصعب ومن البسيط إلى المركب الاسترشاد بنتائج الدراسات السابقة عند وضع البرنامج

خصائص محتويات البرنامج

تثبيث زمن التطبيق اليومي لتجربة البحث ب( •؟) دقيقة خلال الوحـدة

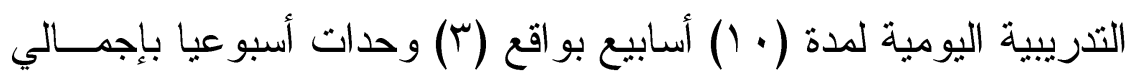

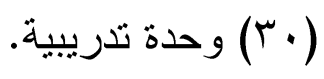

التوزيع الزمني للبرنامسج التدريبي المقترح :

$$
\begin{aligned}
& \text { ق) } \\
& \text { *"التهيئة البدنية (الإحماء) . } \\
& \text { (1.) } \\
& \text { *الإطالة العضلية . } \\
& \ddot{\theta}(\varepsilon \cdot) \\
& \text { * التدريبات البصرية. } \\
& \text { ق) } \\
& \text { • التهدئة و الختام }
\end{aligned}
$$

تم تحديد عدد التدريبات المناسبة للأداء خلال زمــن التطبيــق ب (Y I)

$$
\text { تدريب موزعة كالتالي : }
$$

- تدريبات للمحافظة على ثبات وضع الر أس (r) تدريبات يومية - - تدريبات لتتمية الدقة البصرية الثابتة و المتحركة (ب) تدريبات يوميا

$$
\text { - تدريبات لتحسين مسافة الرؤية (r) تدريبات يومية }
$$

- تدريبات لتنمية الإدر الك البصري (r) تدريبات يوميا

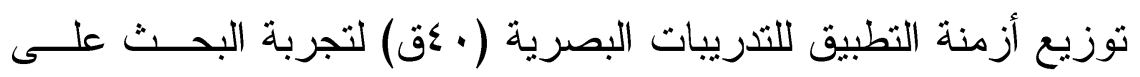

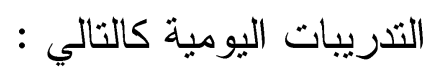

( • (ق) تدريبات للمحافظة على ثبات وضع الر أس (سق) لكل تدريب ،

$$
\text { ( • (ث) راحة للانتقال إلى التدريب التالي . }
$$


( • (ق) تدريبات لتتمية الدقة البصرية (سق) لكل تدريب ، ( • اث) راحة للانتقال إلى التذريب التالي •

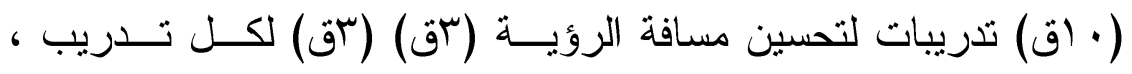

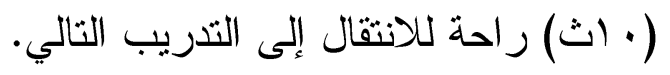

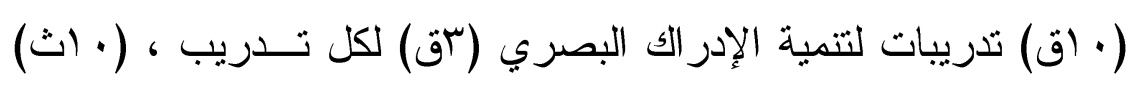
راحة للانتقال إلى التدريب التالي .

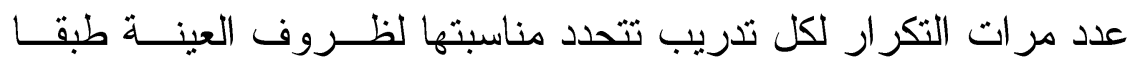

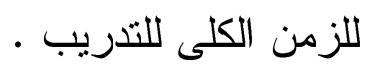
خطوات تتفيذ البحث: القياسات القبلية :

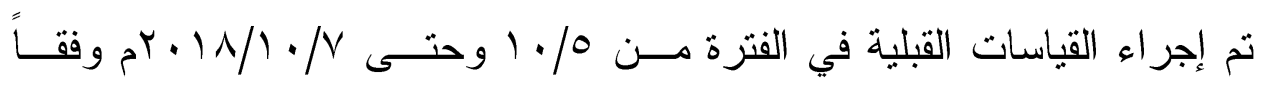

$$
\begin{aligned}
& \text { للترتيب النالي : } \\
& : 5 r \cdot 11 / 1 \cdot / 4 \text { ، } 0 \\
& \text { *اختبار ات الوظائف البصرية. } \\
& : \text { a } 1 \cdot / 1 \cdot / v \\
& \text { تنفيذ تجربة البحث : }
\end{aligned}
$$

تم تتفيذ وحدات البرنامج التدريبي المقترح فـي الفتـرة مسـن · 1/ • 1 وحتـى

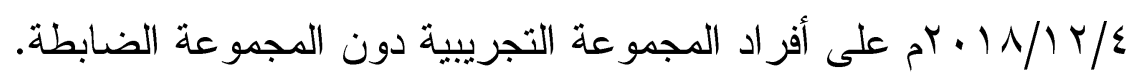
القياسات البعدية : البية

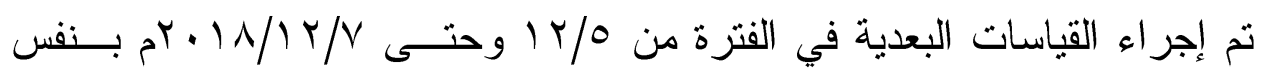
ترتيب القياسات القبلية . المعالجات الإحصائية : المبات وقد تضمنت خطة المعالجة الإحصائية للبيانات الأولية: المتوسط الحسابى الإنحر اف المعيارى 


$$
\begin{aligned}
& \text { • الوسبط } \\
& \text { معامل ارتباط بيرسون } \\
& \text { معامل الالتو اء } \\
& \text { إختبار "ت" . } \\
& \text { عرض ومناقشة الاتنائج : } \\
& \text { أولا - عرض التتائج : } \\
& \text { (r) جدول }
\end{aligned}
$$

\begin{tabular}{|c|c|c|c|c|c|c|c|}
\hline \multirow{2}{*}{ قيمة "ت" } & \multicolumn{2}{|c|}{ القباس البعدي } & \multicolumn{2}{|c|}{ القياس القبلي } & \multirow{2}{*}{ وحدة } & \multirow{2}{*}{\multicolumn{2}{|c|}{ القياس }} \\
\hline & ع & קי & $\varepsilon$ & קp & & & \\
\hline$* \uparrow .00$ & 1.89 & $1 r \ldots$ & $1 . r r$ & $9.1 \mathrm{r}$ & درجة & العين والبد & التوافق بيز \\
\hline$* v . \cdot r$ &. .01 & $\Lambda . \wedge \varepsilon$ &..$M O$ & q.VV & 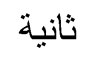 & العين و القدم & التوافق بيز \\
\hline$* V .10$ & l.Vr & $1 Y .9 \mathrm{~V}$ & 1.79 & $\mid 1.21$ & درجة & & الاقة البص \\
\hline$* ฯ . \wedge \mathrm{V}$ &.$M^{\prime}$ & r.r. & .ro & r.А५ & ت ت تانية & مرية & الأكرة البص \\
\hline$* \vee . \diamond \xi$ & $1.0 \mathrm{r}$ & $\Lambda . V$. & $1 . \varepsilon V$ & $0 . M 1$ & درجة & & التببع البص \\
\hline$* q . \wedge$. & $\cdots v$ &.$\vee \vee \wedge$ & $\ldots 0$ &.$\wedge 0$ & ثانية & فعل البصرية & سرعة رد \\
\hline$* \vee .00$ &.$r v$ & $\varepsilon . \wedge 1$ &. .01 & $0 . \wedge \wedge$ & سم & • من مسافة • 1 سم & \\
\hline$* V . r r$ &. .89 & 7.19 &..$\varepsilon r$ & 8.77 & سم & • من مسافة · r سم & \\
\hline$* \eta . \Lambda$. &..$\varepsilon r$ & $V . r \wedge$ &. .00 & $q . \varepsilon r$ & 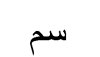 & • من مسافة • ب سم & \\
\hline *o.r. & r.OH & VY.Y & Y. $\{q$ & $70 . \mathrm{M}$ & سم & - ـ رأسي لأعلى & \\
\hline$* 0 . Y \varepsilon$ & r.1I & Vr.. $\varepsilon$ & r.ls & 70.19 & سم & " • ر أسي لأسفل & إدر الك مجال \\
\hline$* \wedge . . \varepsilon$ & $r . \varepsilon q$ & $\Lambda \varepsilon . \varepsilon 0$ & r.tr & VI.Vr & سم & | أفقي يمين & الروئية \\
\hline$* \wedge .90$ & Y.VY & A..r. & T.Y $\varepsilon$ & VY.AI & سم & شمال & \\
\hline
\end{tabular}

دلالة الفروق بين القياسين القبلي والبعدي للمجموعة التجريبية في متغيرات الوظائف البصرية قيد البحث

$1 \cdot=\dot{0}$

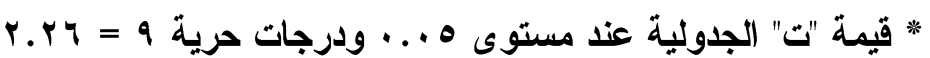


يتضح من الجدول رقم (r) وجود فروق دالة إحصائياً عند مستوى ه . . بين القياسين القبلي و البعدي للمجموعة التجريبية في جميع متغير ات الوظـــائف البصــرية وذللك لصالح القياس البعدي.

$$
\text { جدول (\&) }
$$

دلامة الفروق بين القياسين القبلي والبعدي للمجموعة الضابطة في متغيرات الوظائف البصرية قيد البحث ن = . 1.

\begin{tabular}{|c|c|c|c|c|c|c|c|}
\hline \multirow{2}{*}{ قيمة "ت" } & \multicolumn{2}{|c|}{ القياس البعدي } & \multicolumn{2}{|c|}{ القياس القبلي } & \multirow{2}{*}{ القياس } & \multirow{2}{*}{\multicolumn{2}{|c|}{ القياس }} \\
\hline & ع & pp & ع & pe & & & \\
\hline$* r . \varepsilon r$ & $1 . \wedge r$ & 1.00 & 1.79 & $9 . \leqslant 9$ & درجة & \multicolumn{2}{|c|}{ التو افق بين العين و اليد } \\
\hline$* r .11$ & $.0 \leqslant$ & 9.17 & r. & 9.79 & ثانية & \multicolumn{2}{|c|}{ التو افق بين العين والقدم } \\
\hline$*$ *.rq & 1.19 & 14.09 & I.AV & $11 . r 9$ & درجة & \multicolumn{2}{|c|}{ الدقة البصرية } \\
\hline 1.87 &..$\leqslant 4$ & r.Vr &..$r \Lambda$ & r.A. & 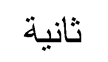 & \multicolumn{2}{|c|}{ الأكرة البصرية } \\
\hline 1.09 & $1.7 \mathrm{~V}$ & 0.94 & 1.00 & 0.11 & درجة & \multicolumn{2}{|c|}{ التبع البصري } \\
\hline $.9 \mathrm{~V}$ & $\cdots \wedge$ & . . & $\ldots 9$ &.$\wedge \varepsilon$ & 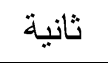 & \multicolumn{2}{|c|}{ سرعة رد الفعل البصرية } \\
\hline r.. I &.$v 1$ & $0 . .9$ & $\cdots \leqslant 9$ & 0.91 & سم & | من مسافة . ( سم & \multirow{3}{*}{ الروئية } \\
\hline$r . . r$ &..$\wedge r$ & $7.9 \mathrm{~V}$ & $\cdot . \wedge \mathrm{V}$ & $v .09$ & 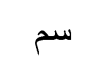 & •• من مسافة •r سم & \\
\hline 1.99 & $\because v 9$ & $\Lambda . \leqslant 7$ &. .71 & $9 . \mathrm{r}$ & سم & • من مسافة • ب سم & \\
\hline$\because \vee \wedge$ & r.Ar & TA.TV & r.OV & $79 . .9$ & 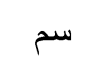 & |- ر أسي لأعلى & \multirow{4}{*}{ إلرال } \\
\hline. .79 & r.V4 & 79.10 & $r . r q$ & $70 . r \varepsilon$ & 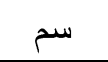 & •• ر أسي لأسفل & \\
\hline 1.09 & $r .71$ & Vq.Tr & $r .00$ & VT. I $\varepsilon$ & 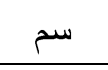 & |- أفقي بمين & \\
\hline $1 . r v$ & r.91 & VQ.r & r.rq & $\mathrm{V} 1.9 \mathrm{~V}$ & سم & | - أفقي شمال & \\
\hline
\end{tabular}

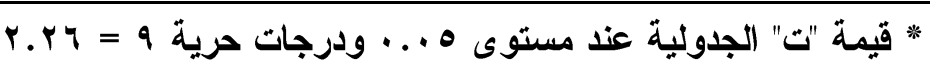
يتضح من الجدول رقم (ع) وجود فروق دالة إحصائياً عند مستوى ه ه . • بين القياسين القبلي و البعدي للمجموعة الضـابطة في متغيرات التوافق بين العـين واليـــــ ، التو افق بين العين و القدم والدقة البصرية ، و عدم وجود فروق فــي بــاقي الوظــائف

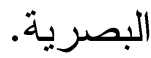


جدول (0)

دلامة الفروق بين القياسين البعديين للمجموعتين التجريبية والضابطة في

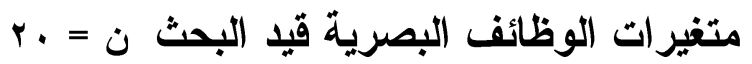

\begin{tabular}{|c|c|c|c|c|c|c|c|}
\hline \multirow{2}{*}{ قيمة "ت" } & \multicolumn{2}{|c|}{ القياس البعدي } & \multicolumn{2}{|c|}{ القياس القبلي } & \multirow{2}{*}{ وحدة } & \multirow{2}{*}{\multicolumn{2}{|c|}{ المتغير ات }} \\
\hline & ع & rp & $\varepsilon$ & ip & & & \\
\hline$* \varepsilon . r \varepsilon$ & $1 . \wedge \mu$ & $1 . .00$ & 1.89 & $1+\ldots$ & درجة & \multicolumn{2}{|c|}{ التوافق بين العين واليد } \\
\hline $1 . \wedge \wedge$ & $.0 \varepsilon$ & 9.17 &. .01 & $\wedge . \wedge \varepsilon$ & ثانية & \multicolumn{2}{|c|}{ التوافق بين العين والقدم } \\
\hline..$\leqslant \square$ & $1 . \wedge 9$ & 17.09 & I.Vr & Ir.9V & درجة & \multicolumn{2}{|c|}{ الاقة البصرية } \\
\hline$*$ *.qr & $\cdot . \leqslant 7$ & Y.VY &.$M_{1}$ & r. r r & ثانية & \multicolumn{2}{|c|}{ الأكرة البصرية } \\
\hline$* \bullet . r r$ & $1.7 \mathrm{~V}$ & 0.94 & $1.0 \mathrm{r}$ & $\Lambda . \vee \cdot$ & درجة & \multicolumn{2}{|c|}{ التتبع البصري } \\
\hline$*$ Y.०. & $\cdots \wedge$ &.$\Delta r$ & $\because v$ &.$\vee \vee \wedge$ & ن ئية & \multicolumn{2}{|c|}{ سرعة رد القعل البصرية } \\
\hline 1.70 &. .21 & 0.9 &.$r V$ & $\varepsilon . \wedge 1$ & سم & • من مسافة ، ا سم & \multirow{3}{*}{ إلدر الك } \\
\hline$*$ *. $q$ &.$\Delta r$ & $7.9 V$ &..$\varepsilon 9$ & $7 . r 9$ & سم & • من مسافة • ب سم & \\
\hline$* 0.1 \varepsilon$ &..$\vee q$ & $\Lambda . \varepsilon \uparrow$ &.$\varepsilon r$ & V.rA & سم & • من مسافة • ب سم & \\
\hline$* 0.7 r$ & $r . \wedge r$ & $\neg \wedge . \mathrm{TV}$ & Y.or & VY.Y & سم & - ـ رأسي لأعلى & \multirow{4}{*}{ الدرال } \\
\hline$* \varepsilon . \vee \varepsilon$ & Y.VY & 79.10 & Y.1I & Vr.. $\varepsilon$ & سم & - ـ رأسي لأسفل & \\
\hline$* V . \ldots$ & $r .7 \wedge$ & VY.T & $r . \varepsilon q$ & $\wedge \varepsilon . \varepsilon 0$ & سم & ـ أفقي يمين & \\
\hline$* 9.94$ & 9.91 & VO.ME & Y.VY & Ao.r. & سم & | أفقي شمال & \\
\hline
\end{tabular}

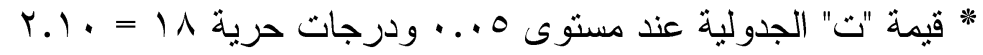
بتضح من الجدول رقم (0) وجود فروق دالة إحصائياً عند مستوى 0 . . بين القياسين البعديين للمجموعتين التجريبية و الضابطة جميع متغيرات الوظائف البصــرية لصالح القياس البعدي للمجموعة التجريبية عدا التو افق بـين العـين والقــدم ، الدقــة البصرية و إدر الك عمق الرؤية من مسافة • ـ سم. 
ثانيا - مناقشة النتائج

يتضح من الجدول رقم (س) وجود فروق دالة إحصائياً عند مسنوى 0 . . بين القياسين القبلي و البعدي للمجموعة التجريبية في جميع متغير ات الوظـــائف البصــرية وذلك لصالح القياس البعدي.

ويتضح من الجدول رقم (ع) وجود فروق دالة إحصائياً عند مستوى ه . . بين

القياسين القبلي و البعدي للمجموعة الضـابطة في متغير ات التوافق بين العـين واليــــ ،

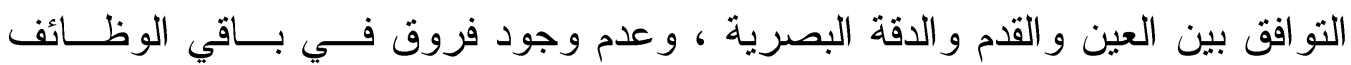

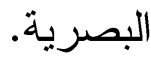

كما يتضح من الجدول رقم (0) وجود فروق دالة إحصائباً عند مستوى 0. .. بين القياسين البعديين للمجمو عتين التجريبية و الضابطة في جميع متغيرات الوظــائف البصرية لصالح القياس البعدي للمجموعة التجريبية عدا التوافق بين العـين والقــدم ، الدقة البصرية و إدر الك عمق الرؤية من مسافة ـ ـ سم. ويعزى الباحث ذلك إلي اقتتاع عينة البحث بأهمية جـدوى ممارســة التـدريب البصري لتنمية القدرات البصرية على المدى الزمني الطويل لتدريب العين، بالإضافة إلى ترقية المستوى الفني خلال المنافسات كما يعزي الباحث ذلك إلى تــأثير برنـامج

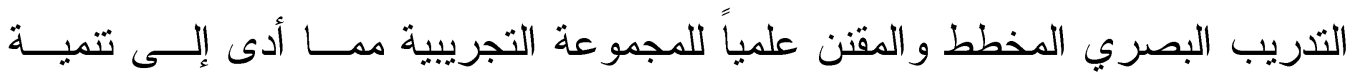
القدر ات البصرية بالإضافة إلى اتسام برنامج التدريب البصري بالتكامل و الثمول فـي تتمية القدرات البصرية الذي كان له الأثر الإيجابي الفعال في تحسن القدرات البصرية للمجمو عة التجريبية

بالإضافة إلى اشتمال البرنامج التدريبي على التدريبات المتتوعة لعضلات العين و التي أصبحت من الأهمية بمكان لتتمية القدرات البصرية المختلفة كالتركيز البصري

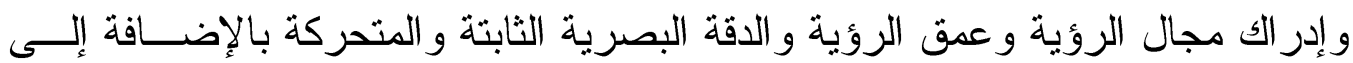

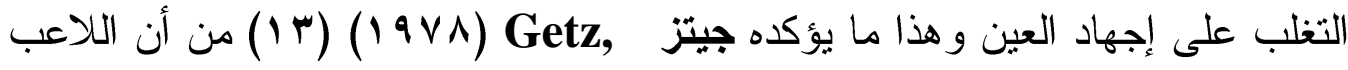


أثثاء التتافس يتعرض للعديد من الضغوط العقلية و البدنيــة ، و ونتيجـــة لـــللك تصــبـح المستقبلات الحسية (خاصة المحلل البصري) مضطربة ، فالحساسية الكهربائية للعـين تقل تحت ظروف الإجهاد البدني ، و انخفاض مستويات الأكسجين يسبب هبــوط فـي اليـي

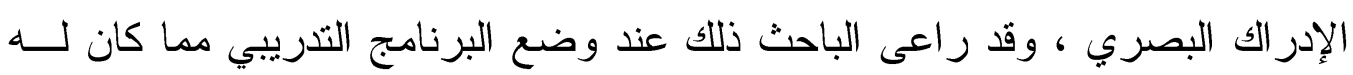
الأثر الإيجابي الفعال في تحسن القدرات البصرية للمجموعة التجريبية دون المجموعة الضابطة.

وفي هذا الصدد يؤكد فيصل حسن Feisal Hassan (ع . . r) (r I ) ووليـامز

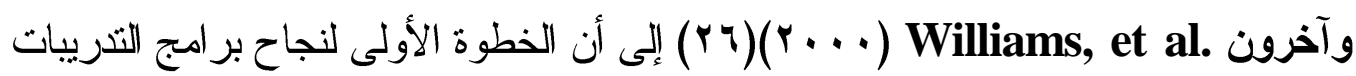

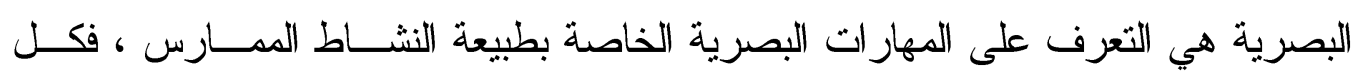
رياضة لها من المهار ات البصرية ما يميزها عن الرياضات الأخرى.

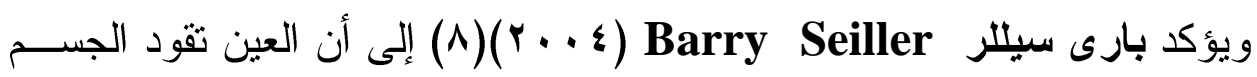

للأداء ، فاللاعب يؤدى كنتيجة للمعلومات النوعية البصــرية ،و القــدرات البصــرية

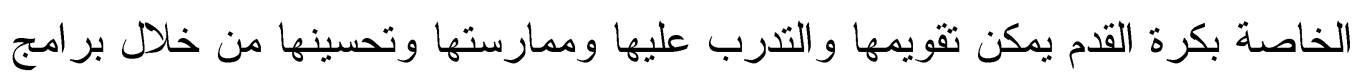

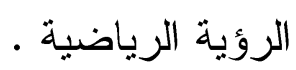

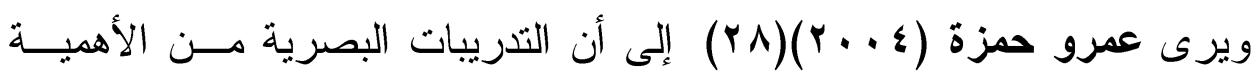

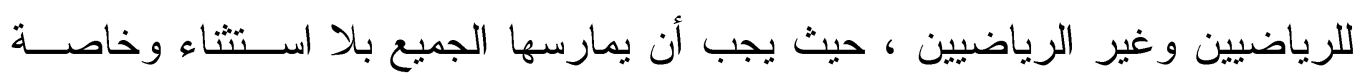

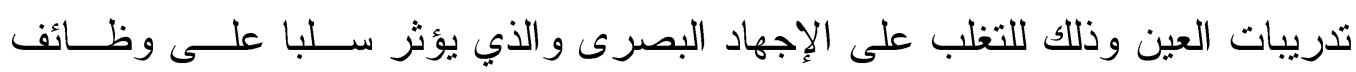
الإبصار مع مرور الزمن.

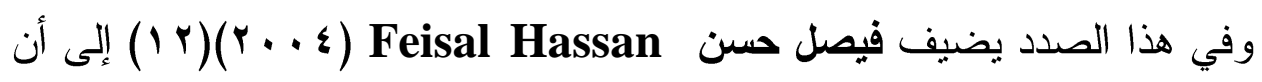
كرة القدم من الرياضات التي تلعب فيها القدرات البصرية دورا هاما يتضح من خلال

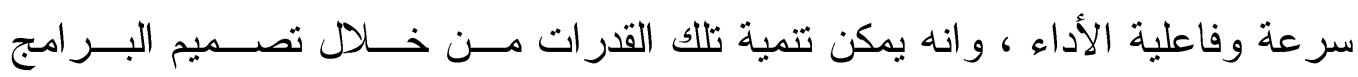
البصرية بصورة جيدة. 
Quevedo, et al. وتتفق نتائج الدر اسة مع در اسة كلا من كويفيدو وآخرون

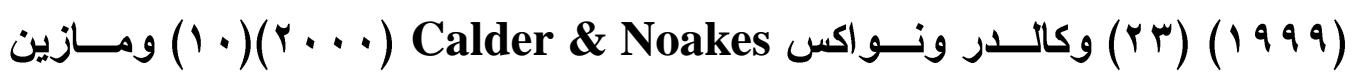

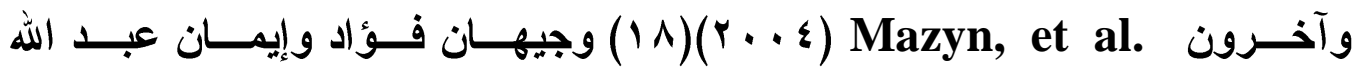

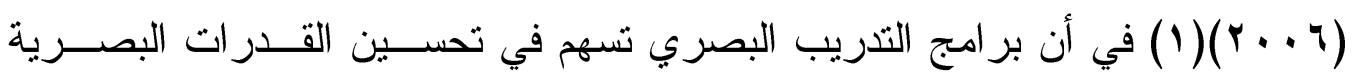

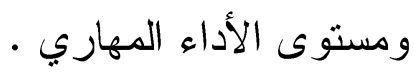

الاستخلاصات :

في ضوء أهداف وفروض البحث وفي حدود العينة واستتادا إلى ما أسفرت عنه المعالجات الإحصائية أمكن التوصل إلى أن :

برنامج التذريبات البصرية اثبت فاعلية في تحسين الوظائف البصرية

تطبيق البرنامج التدريبي البصري المقترح على ناشئ كرة القدم

ضرورة الاهتمام بتفعيل دور التدريبات البصرية في المجال الرياضــي بصفة عامة وفي رياضة كرة القدم بصفة خاصة

ضرورة تو افر أخصائي بصري يقوم بتقويم وتنمية القدر ات و الوظــائف البصرية للاعبين وتحديد نوع النظار ات و العدسات اللاصقة من حيــث الكفاءة و اللون لحماية اللاعب

إجر اء المزيد من الدراسات التي تتناول اثر التــدريبات البصــرية فــي رياضات أخرى و على عينات مختلفة

إنشاء معمل خاص بالقياسات البصرية داخــل معامـلـل كليــة التزبيـــة الرياضية 


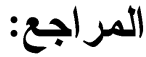

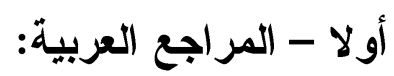

1- جيهان فؤاد و إيمان عبد الله (؟ + . ץ): فاعلية التدريب البصري على بعض

المتغير ات المهارية والقدر ات البصرية في الكرة الطائرة ، بحث منشور،

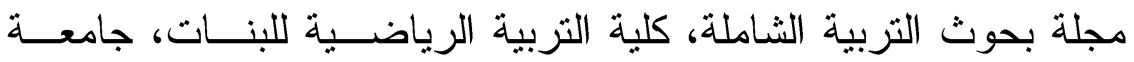

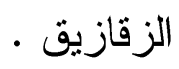

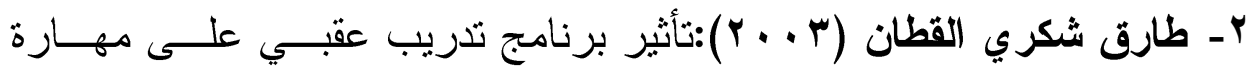

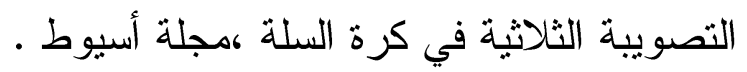

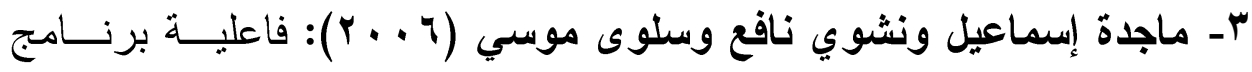

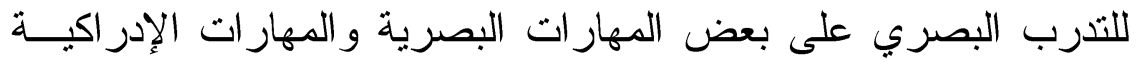

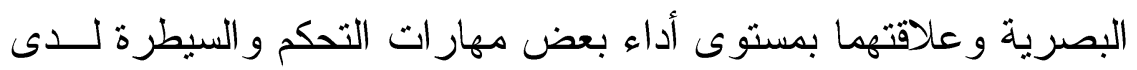
ناشئات الجمباز الإيقاعي، بحث منشور، مجلة بحوث التزبية الثــاملة، كلية التربية الرياضية للبنات، جامعة الزقازيق.

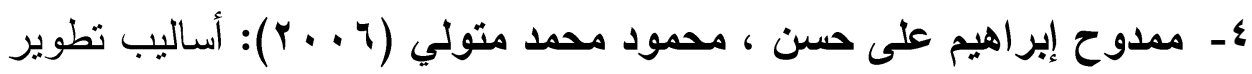

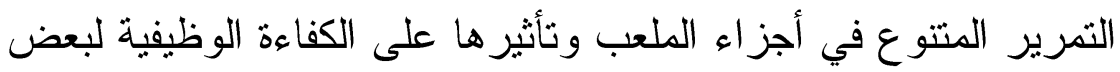

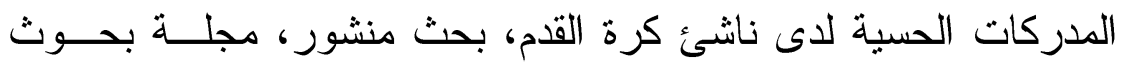
التربية الرياضية للبنين، جامعة الزقازيق، يناير.

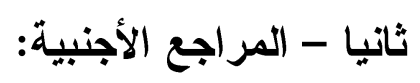

5- Alida Anelia Ludeke (2003):The visual skills of professional and amateur rugby players, Dissertation , Submitted in fulfillment of the requirements of the master degree, Faculty of science, Rand Afrikaans university 
6- Amr Hamza ,Ashraf khattab, Merfat rashad (2005) : effect of visual training on static balance and vision abilities for fencers, European congress of sports medicine, Serbia and Montenegro.

7- Asseman F, Caron O, Cremieux J (2005): Effects of the removal of vision on body sway during different postures in elite gymnasts, Int J Sports Med. Mar;26(2):116-9

8- Barry Seiller (2004): Positive Effects of a Visual Skills Development Program, Optometry \& Vision Science. 79(5):279-280

9- Brian Ariel (2004): Sports Vision Training: An expert guide to improving performance by training the eyes, Human Perception and Human Performance, 8, 127-136

10- Calder, S. \& Noakes, T. (2000):A specific visual skills training programme improves field hockey performance , 2000 PreOlympic Congress Sports Medicine and Physical Education International Congress on Sport Science 7-13 September Brisbane, Australia

11- Erickson G. (2007). Sports Vision: Vision Care for the Enhancement of Sports Performance. St. Louis, MO, Butterworth-Heinemann Elsevier.

12- Feisal Hassan. (2004): Acquiring vision skills essential for tennis , Perceptual \& Motor Skills, 70, 131-141.

13- Getz DJ. (1978). Vision and Sports. Journal of the American Optometric Association, 49 (4) 385-388.

14- Isabel walker(2001): Why visual training programmes for sport don't work, Sports Sci, Mar 19(3) p203-22.

15- Lemmink KA, Dijkstra B, Visscher C (2005): Effects of limited peripheral vision on shuttle sprint performance of soccer players, Percept Mot Skills. Feb;100(1):167-75.

16- Lenoir M, Crevits L, Goethals M, Wildenbeest J, Musch E. (2000). Saccadic eye movements and finger reaction times of table tennis players of different levels, Neuro-ophthalmology, Vol. 24,No. 2, pp. 335-338

17- Manish Singh and Donald D. Hoffman (1998). Active vision and the basketball problem, Behavioral And Brain Sciences 21:6.pp 771-773

18- Mazyn LI, Lenoir M, Montagne G, Savelsbergh GJ. (2004): The contribution of stereo vision to one-handed catching , Exp Brain Res. 2004 Aug;157(3):383-90. Epub 2004 Jun 25

19- McLeod, B. Hansen H.(1989): Effects of Eyerobics visual training for soccer. A reply. Perceptual Motor Skills. 72(3). 863-866. 
20- Millslagle , D (2004): Coincidence anticipation and dynamic visual acuity in young adolescents. , Percept Mot Skills. Dec;99(3 Pt 2):1147-56

21- Pieer Elmurr (2010). Assessing and Training Eye-Hand Coordination. Sport vision Australia, Summer 8-10.

22- Paul Maman, Shukla Gaurang \& Sandhu J. S.(2011): the effect of vision training on performance in tennis players, Serbian Journal of Sports Sciences, 5(1): 11-16

23- Quevedo L,Sole J, Palmi J, Planas A, Soana C. (1999): Experimental study of visual training effects in shooting initiation, Clin Exp Optom. Jan;82(1):23-28.

24- Quintana MS, Roman IR, Calvo AL, et al. (2007). Perceptual visual skills in young highly skill basketball players. Percept Mot Skills ;104: 547-561.

25- Tate Balasaheb, Paul Maman, \& Sandhu JS(2008), the impact of visual skills training program on batting performance in cricketers, Serbian Journal of Sports Sciences,2(1): 17-23

26- Williams AM, Davids $K$ and Williams JG. (2000). Visual perception and action in sport, Routledge New York.

27- Zieman AN, Hascelik, Z., Basgoze, 0. Turker, K., Narman, S., \& Ozker, R. (1993): The effects of physical training on physical fitness tests and auditory and visual reaction times of volleyball players. Journal of Sports Medicine \& Physical Fitness, 29(3), 234-239.

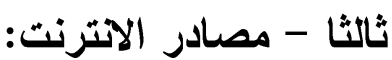

28- http://www.iraqacad.org/Lib/amro.htm

29- http://www.avca.org/homecourt.htm

30- http://www.vision3d.com/VTdocs.html 